\title{
THE INSURANCE INDUSTRY: A CASE STUDY IN THE WORKABIL- ITY OF REGULATED COMPETITION *
}

\author{
Joer B. Dirlam $\dagger$ and Irwin M. Stelzer $\ddagger$
}

\begin{abstract}
Public Law 15, which preserves to the states their right to regulate the business of insurance, represents an implicit decision, not only for state as against federal control, but also for linited rather than full-bodied competition. It represents an effort, the Authors argue, to foster a scheme of regulation compatible with continued competition. In this Article they weigh the effectiveness of state regulation and call for reforms to permit a greater extent of price competition in the insurance industry. Mr. Dirlam and Mr. Stelzer have combined forces to produce articles in the field of antitrust in the past, and each has written extensively about the operation of the free enterprise system.
\end{abstract}

\section{INTRODUCTION}

The authors propose in this Article to appraise, on the basis of the latest available evidence, the experience of the insurance industry since the Supreme Court's ruling in United States $v$. South-Eastern Underwriters Ass'n. ${ }^{1}$ That decision touched off a chain of events which resulted in more intensive state regulation of many aspects of the insurance business ${ }^{2}$ and partially exempted it from various provisions of the antitrust laws. By re-examining ${ }^{3}$ the mechanisms that were set

* The authors would like to thank Miss Lila Abramson for her valuable research assistance.

$\dagger$ Associate Professor, Department of Economics, University of Connecticut. A.B., 1936, Ph.D., 1947, Yale University.

† Vice President, Boni, Watkins, Jason \& Co., New York. A.B., 1951, New York University; M.A., 1952; Ph.D., 1954, Cornell University.

1. 322 U.S. 533 (1944). This reversal of the lower court ruling (see 51 F. Supp. 712, D. Ga. 1943) was accomplished without directly overruling the seventy-five year old doctrine laid down in Paul v. Virginia, 75 U.S. (8 Wall.) 168 (1868). Justice Black, speaking for the Court, noted that the Paul decision had only held that the commerce clause does not deprive the states of the power to regulate and tax insurance. Neither Paul nor any other case had required the Court to decide whether Congress had the power to regulate insurance transactions stretching across state lines. Black emphasized that "legal formulae designed to uphold state power cannot uncritically be accepted as trustworthy guides to determine Congressional power under the Commerce Clause." 322 U.S. at 545.

2. Many states were already regulating various aspects-including rates-of the industry. See Whitney, ANTITRust Policies: AMERICAN Experience IN Twenty INDUSTRIES (1958).

3. In an earlier study one of the authors concluded that, as a result of the SouthEastern Underwriters case, several undesirable practices were eliminated, others were placed under state regulation, and consumers benefited from lower, more equitable rates, a greater variety of rates, and more rational rate-making. See Stelzer, The Insurance Industry and the Antitrust Laws: A Decade of Experience, 1955 INS. L.J. 137-52. 
up to supervise and regulate the operation of the insurance industry, it is hoped that some constructive conclusions can be reached concerning the adequacy of that regulation in meeting the needs of both the insuring companies and the insured public. Further, this analysis will, we hope, be of interest to those concerned with the broader problems raised by the substitution of formal administrative regulation for the informal regulation provided by the competitive market place.

\section{Public Law 15}

The fundamental purpose of Public Law $15^{4}$ was stated to be the preservation to the states of their right to regulate the business of insurance. ${ }^{5}$ Since antitrust seemed to be the immediate expression of federal intervention, the statute provided that-except for acts of boycott, intimidation or coercion-the antitrust laws would apply to the business of insurance only in the absence of state regulation. ${ }^{6}$ Although Public Law 15 does not expressly declare that, to be insulated from the thrust of federal power, the states must impose regulation which is effective, ${ }^{7}$ there can be no doubt that Congress and the President ${ }^{8}$ assumed that effective state regulation was necessary to avoid federal intervention. Thus, Senator O'Mahoney, shortly after passage of the bill, noted that "the antitrust laws . . . are revived in all their vigor if state regulation fails," ${ }^{\circ}$ and the Assistant Attorney General in charge of the Antitrust Division recently stated, "I do not believe that an exemption exists for these activities [price-fixing, etc.]

4. 59 Stat. 33 (1945), as amended, 15 U.S.C. $\$ \$ 1011-15$ (1952). For legislative history see House Legislative Calendar, 79th Cong., 1st \& 2 d Sess., Committee on the Judiciary, Jan. 29, 1946, No. 22, at 103. Congressional debate may be found in 91 CoNG. REC. $478-88,1085-93,1442-44,1477-89$ (1945).

5. The preamble states: "That the Congress hereby declares that the continued regulation and taxation by the several States of the business of insurance is in the public interest, and that silence on the part of the Congress shall not be construed to impose any barrier to the regulation or taxation of such business by the several States." 59 Stat. 33 (1945), 15 U.S.C. \$ 1011 (1952).

6. Section 3(a) states, "Until January 1, 1948, ... the Sherman Act, . . . the Clayton Act, . . and . . . the Robinson-Patman Anti-discrimination Act shal1 not apply to the business of insurance or to acts in the conduct thereof." Section 3(b) adds, "Nothing contained in this Act shall render said Sherman Act inapplicable to any agreement to boycott, coerce, or intimidate, or act of boycott, coercion or intimidation." 61 Stat. 448 (1947), as amended, 15 U.S.C. \$ 1013 (1952).

7. Section 2(b) states only that, upon expiration of the moratorium the antitrust laws "shall be applicable to the business of insurance to the extent that such business is not regulated by State Law." 59 Stat. 34 (1945), 15 U.S.C. \& 1012 (1952).

8. In a statement issued upon signing the bill, March 10, 1945, President Roosevelt said that antitrust laws after the moratorium would be "applicable in full . . . except to the extent that the States have assumed the responsibility and are effectively performing that responsibility for the regulation. . . . Congress did not intend to permit private price fixing." 13 Public Papers and AdDresses of Franklin Delano Roosevelt 587 (Rosenman ed. 1950).

9. Speech reprinted in Government and the Insurance Business, 7 Casualty AND SuRETY J. 13 (1946). 
merely because a state has legislated, if it does not adequately enforce its regulations." 10 The key issue, therefore, is not whether the states have passed regulatory legislation, ${ }^{11}$ but whether state regulation has, in practice, been effective. ${ }^{12}$ Any appraisal of the effectiveness of state regulation must be made, however, with the realization that the sanctioned continuance of state regulation involved an implicit decision, not only for state as against federal control, but for a limited as against a full-bodied type of competition. This decision for partial antitrust exemption is, of course, not without precedent. Rail, air and water carriers, for example, may file with their respective regulatory agencies agreements concerning rates and other matters. ${ }^{13}$ These exemptions do not, however, license these industries to impose cartel restraints on their members. Railroads, for instance, may not agree to a pooling or division of traffic and must be accorded "the free and unrestrained right to take independent action" either before or after a Commission rate determination. ${ }^{14}$

The argument which has long been used to justify regulation of the insurance industry, and which was marshalled to justify the partial antitrust exemption of Public Law 15, is that the rate competition which would result from a full-scale enforcement of the Sherman Act ${ }^{15}$ is undesirable. Because of certain unique characteristics of the business of insurance, the argument continues, such competition would become destructive. Some of these unique characteristics follow: ${ }^{16}$

(1) A complicated financial contract makes it impossible for the policyholder to determine value received.

10. Hansen, Insurance and the Antitrust Laws, The Insurance Broker-Age, Oct. 1957 , p. 35.

11. For a review of legislation adopted see Stelzer, supra note 3, at 146-48.

12. FTC v. National Cas. Co., 355 U.S. 867 (1958), sustained circuit court dismissals of Federal Trade Commission complaints against insurance advertising, on the ground that the McCarran-Ferguson Act prohibited such intervention where states had passed laws explicitly prohibiting unfair and deceptive insurance practices. The Supreme Court refused to entertain an FTC contention that, even though the statutes were not "mere pretense," unless they had crystallized into settled administrative procedure they were ineffective and hence inoperative as a bar to federal action. In so deciding, the Court held that while there might be a difference between "legislation" and "regulation" nothing in the act supported the particular distinction which the FTC attempted to draw. Cf. Kenney, Why This Jubilation at Supreme Court Decision on $A$ \& $H$ Insurance?, 69 U.S. INVESTOR 51 (1958).

13. See Interstate Commerce Act, 24 Stat. 380 , as amended, 49 U.S.C. \$5b (1952) ; 52 Stat. 1004, as amended, 49 U.S.C. \$ 492 (1952).

14. 24 Stat. 380, as amended, 49 U.S.C. $\$ 5 b$ (1952). See also REPORT of THE Attorney General's National Committee To Study the ANTitrust Laws ch. VI (1955).

15. 26 Stat. 209 (1890), as amended, 15 U.S.C. $\S \S 1-7$ (1952).

16. For a classic statement of the characteristics of the insurance industry making unlimited competition undesirable, see German Alliance Ins. Co. v. Kansas, 233 U.S. 389 (1914). See also summary by Stelzer, supra note 3, at 141 and CowEe \& CENTER, Federal Regulation of Insurance 7, 72-73 (1949). 
(2) The insurer cannot know his costs in advance.

(3) The insurer must maintain continued ability to meet contractual obligations. Consequently, the purchaser of an insurance contract has a continuing interest in the solvency of the obligor. But the insured pays a small amount (initially) relative to what he may receive. Because of this low ratio of premiums to possible liability, a company may be tempted to cut rates drastically in order to increase the number of its policyholders. As a consequence, solvency may be threatened.

(4) Reliable rate-making requires combining the experience of many insurance carriers.

Our subsequent discussion will attempt to determine whether regulation of the insurance industry, ${ }^{17}$ as conducted by the states since the South-Eastern Underwriters case, has managed, in fact, to strike a balance between undue repression of nascent competitive individualism on the one hand and encouragement of cutthroat competition on the other.

\section{The Effectiveness of State Regulation}

\section{A. The Legislative Pattern}

It should be noted that the McCarran Act, as Public Law 15 is known, sets forth no precise standards for state regulation. For instance, the act does not even mention rating bureaus. It was left to the National Association of Insurance Commissioners, together with the All-Industry Committee, ${ }^{18}$ to draft model bills which would indicate the proper future course for state regulation.

The stated purpose of the model rate regulatory laws was to ensure that rates would not be "excessive, inadequate, or unfairly discriminatory," and, at the same time, to authorize and regulate rating bureaus without discouraging competition. ${ }^{19}$ In order to reconcile the official recognition of the role of the rating bureaus with the avowed

17. The different legal and economic conditions under which the life insurance industry operates have led the authors to exclude it from consideration in this Article.

18. For a list of members see Stelzer, supra note 3, at 147.

19. Proposed Casualty and Surety Rate Regulatory Bill; and Proposed Fire, Marine and Inland Marine Rate Regulatory Bill, as cited in The Legislative Record, Feb. 5, 1947 and Dec. 16, 1946, respectively : "Section 1-Purpose of Act. The purpose of this Act is to promote the public welfare by regulating insurance rates to the end that they shall not be excessive, inadequate or unfairly discriminatory, and to authorize and regulate co-operative action among insurers in rate making and in other matters within the scope of this Act. Nothing in this Act is intended (1) to prohibit or discourage reasonable competition, or (2) to prohibit, or encourage except to the extent necessary to accomplish the aforementioned purpose, uniformity in insurance rates, rating systems, rating plans or practices. This Act shall be liberally interpreted to carry into effect the provisions of this Section." 
purpose of preserving some measure of rate competition, independent filings and deviations from bureau rates and classifications were expressly permitted. ${ }^{20}$

While many of the model laws were passed in virtually all the states ${ }^{21}$ they were adopted with varying degrees of exactitude, so that uniformity does not prevail. Further, since neither the model laws nor the statutes adopted set out specific standards for determining whether a rate is "excessive, inadequate, or unfairly discriminatory," the possibility, even the likelihood, exists that insurance commissioners and state courts may arrive at nonuniform, even conflicting, interpretations of the statutes, whether as applied to rates arrived at by the bureaus or as applied to particular deviations from them.

Clearly, an examination of the functioning of regulation under the new legislation is necessary to determine not only whether the principles of the model laws themselves have been upheld but whether the sum total of this regulatory experience approaches the effective regulation envisaged by Public Law 15. ${ }^{22}$ While it would be of great assistance to have a detailed analysis of the policies of each state toward competition, and toward rate and classification deviations, a more limited survey can provide a basis for appraisal.

20. Proposed Fire, Marine and Inland Marine Rate Regulatory Bill, supra note 19, \&7: "[A]ny insurer may make written application to the [commissioner] for permission to file a deviation from the class rates, schedules, rating plans or rules. . . . The [commissioner] shall issue an order permitting the deviation for such insurer to be filed if he finds it to be justified. . . ."

Proposed Casualty and Surety Rate Regulatory Bill, supra note 19, §7: "Every member of or subscriber to a rating organization .. . may make application to the [commissioner] for permission to file a uniform percentage decrease or increase to be applied to the premiums produced by the rating system so filed for a kind of insurance or for a class of insurance which is found by the [commissioner] to be a proper rating unit ... or for a subdivision of a kind of insurance (1) comprised of a group of manual classifications which is treated as a separate unit for rate making purposes, or (2) for which separate expense provisions are included in the filings of the rating organization."

21. As of November 19, 1957, 26 states had adopted the NAIC Rules Governing Advertising of Accident and Sickness Insurance; 41 states and two territories had enacted the State Fair Trade Practices Act; 45 states and three territories had enacted the Uniform Accident and Sickness Policy Provisions Law; 42 states and Hawaii had adopted the Unauthorized Insurers Service of Process Act. See NAtional Association of Insurance Commissioners, Regulation of Advertising SUb-COMMITTTEE REPORT B4-1 (1957).

22. It is clear that one of the pressures for the adoption of state regulatory laws was the threat of federal intervention, as is evidenced by the concluding section of the Texas act to regulate unfair methods of competition in the insurance industry: "The fact that the enactment of this Act will strengthen state regulation of the business of insurance; that substantially the same Act has previously been enacted in thirtynine states, and that it is designed to prevent federal regulation and taxation of the business of insurance creates ast emergency and an imperative public necessity that the Constitutional Rule requiring bills to be read on three several days in each House be susperded; and said Rule is hereby suspended and this Act shall take effect and be in force from and after its passage and it is so enacted" (Emphasis added.) See Tex. S. 191, An Act To Amend Article 21.21 of Chapter 21 of the Insurance Code, 


\section{B. State Regulation in Practice}

\section{Restriction of Entry}

One balkanizing, anti-competitive and apparently unintended effect of Public Law 15 has been to enable various states to limit the ability of "foreign," i.e., out-of-state, insurance companies to compete for business with "domestic" companies. Thus, Public Law 15 provided justification for a South Carolina statute which levied a tax of three per cent on the premiums written in the state by a "foreign" insurance company. Prudential, a New Jersey corporation which was licensed to do business in South Carolina, argued in the courts that as a consequence of the South-Eastern Underwriters decision the taxing power of the state was limited by the commerce clause, and that this tax represented an unconstitutional discrimination against interstate commerce. Although granting that in the absence of the McCarran Act the tax would be unconstitutional, and that all the business done by the insurance company in South Carolina, and thereby affected by the tax, was done "in" or as a part of interstate commerce, the Supreme Court held that the McCarran Act had removed any objections that might be made against the tax under the commerce clause. The Court rejected the argument that Congress lacked the constitutional power to authorize state action that would otherwise be prohibited by the commerce clause. $^{23}$

In the years since this decision was handed down, many if not all of the states have levied premium taxes on out-of-state companies. The burdensome nature of these taxes is increased by the fact that they are not uniform as to rate or rate base. Some states allow a deduction for reinsurance paid, for example, whereas others allow a reduction for reinsurance premiums received. ${ }^{24}$

This ability of the McCarran Act to insulate such legislation from attack on constitutional grounds must be counted against it in our attempt to assess its over-all impact. There can be no economic justification for such a tax. States desiring to protect their citizens from "foreign" companies domiciled in states where regulation is less stringent can surely find more effective tools than what is, in effect, a discriminatory protective tariff.

approved May 8, 1957 (Tex. INs. Cone art. 21.21 (Supp. 1958)). The extent to which this motive outweighed a desire for effective regulation is the subject of psycho-rather than economic -analysis. The impact of state regulation, however, is susceptible to analysis with the economist's tools, and it is to that which we direct ourselves.

23. Prudential Ins. Co. v. Benjamin, 328 U.S. 408 (1946).

24. Mehr \& Cammack, Principles of Insurance 836 (1957). 


\section{Rating Bureaus and Deviations}

Competition in insurance, as in all types of businesses, may take three forms: (1) service, (2) product (policy), and (3) price (premium rates). Conceding the existence, in vigorous degree, of service competition, and not having conducted the elaborate and detailed study of policy provisions necessary to reach significant conclusions concerning the extent of competition in liberalization of policy forms, we confine ourselves here to an assessment of price competition. The paramount problem is to discover the impact on price competition of state laws and their administration; the task is to determine whether, contrary to the directives of the statutes, competition has been discouraged. We hasten to add that it is not at all clear that the statutes were intended to encourage competition; they are, rather, elusively vague, explicitly prohibiting neither competition nor rate uniformity. ${ }^{25}$

The extent of price competition in the insurance industry may, for instant purposes, be inferred in large measure from data on trends in the number of independent' filings and/or deviations. Under the provisions of most state laws, rating bureaus are required to file all rates and forms with the proper state authorities. After a stipulated waiting period, these rates become effective unless found to be inadequate, excessive, or unfairly discriminatory. Individual companies may make independent filings-an insurer is not required to become either a member of, or a subscriber to, a rating bureau-or may file deviations, which are to be approved if they meet the same standards of adequacy, etc., required of bureau rates. ${ }^{26}$ The model bills further permitted individual companies to adopt individual systems of expense allocation. ${ }^{27}$

The extent and intensity of intercompany rate competition in the various states is a function of several factors: (1) the number of insurance companies that desire to determine their own rates, (2) the provisions of the particular state statutes, (3) the regulations and orders of the insurance commissioner issued pursuant to his interpretation of the statutes, (4) the courts' interpretation of the statutes, and (5) the extent and degree of the bureaus' opposition to such independent action.

\section{Cf. note 19 supra.}

26. Stelzer, supra note 3 , at 147.

27. Proposed Casualty and Surety Rate Regulatory Bill, supra note 19, §3(a) (2) and Proposed Fire, Marine and Inland Marine Rate Regulatory Bill, supra note 19, \$3(a) (3). See also Kulp, The Rate Making Process in Property and Casualty Insurance-Goals, Techniques, and Limits, 15 LAW \& CoNTEMP. ProB. 513 (1950); Murphy, Time Ruins Out, 8 CAsUalTy AND SuRETy J. 51 (1947). 
Data now available indicate an increasing tendency in several states to break away from rating bureau domination. In response to a questionnaire mailed by one of the authors to the state insurance commissioners early in 1955, twenty of the twenty-three respondents providing usable answers indicated that they discerned no tendency for the number of independent rate filings (or deviations) to decline since the passage in their states of laws approximating the model rate regulatory bills. ${ }^{28}$ In an attempt to elicit further and more current information on this point, the authors recently circulated another questionnaire to the commissioners. Although response was far from complete, the results are significant. In answer to a question regarding the trend of individual rate filings since 1954, thirteen respondents noted an increase in independent filings and deviations, and six reported no change. (One respondent reported increased independent filings in the casualty and fire fields, and a decrease in the number of such filings in the inland insurance line.)

That the provisions of the statutes and the attitude of the insurance commissioners are of the utmost importance in determining the degree of competition in the industry cannot be doubted. Nor can wide differences in philosophies and policies be denied. Generally, three fairly distinct approaches are discernible: an attempt to maximize and widen the scope of permissible competition, within a framework of regulation; an attempt to limit rate competition to some minimal amount; an attempt to impose clear-cut utility-type rate regulation, with the state commission promulgating rates and permitting no deviation.

New Jersey apparently provides an example of the first type of approach. Its insurance commissioner recently stated-in the course of approving a request of the Merchants Indemnity Corporation of New York for permission to write fire and extended coverage at fifteen per cent below the rates of the Fire Insurance Rating Bureauthat, in his view, "the entire philosophy of the rating laws leans in favor of price competition in this State." 29

In other states, the emphasis on uniformity of rates and policies outweighs any desire to stimulate competition. Thus, the insurance department of Kentucky has sponsored three bills designed to restrict filings of deviations; the bills have met with bitter opposition from the independent companies.

"The bills in question would . . authorize [the commissioner] to adopt uniform forms for any kind of insurance; prevent a company from filing rate schedules or rating plans made

28. Stelzer, supra note 3 , at 151 .

29. Journal of Commerce, Jan. 10, 1958, p. 4. 
by a rating organization of which the company is not a member or subscriber; and prohibit companies... from filing rates made by another insurer." 30

Commissioner Thurman stated that the insurance department needs ample authority to control forms and rates or there would be no intelligent way to find out whether premiums are excessive or inadequate. He further pointed out that a standard policy for fire insurance has been adopted in most states, and that several states, including Massachusetts, Texas and Virginia, have adopted a standard automobile policy. ${ }^{31}$

Finally, Texas provides an example of state imposed rate-setting. Not only has that state adopted a standard automobile policy, but the legislature has given the Board of Insurance Commissioners exclusive power to promulgate and fix reasonable and adequate automobile insurance rates. Companies may write fire insurance at lower than promulgated rates upon a showing that the resulting premiums are adequate, and that the reduced rates apply equally to all risks of the same character in the same community. ${ }^{32}$ For casualty insurance, the board can make or approve premium rating plans designed to encourage the prevention of accidents, recognize the peculiar hazards of individual risks, and give due consideration to interstate as well as intrastate experience. $^{33}$ In addition to this broad and general delegation of power, it is instructive to note that, for casualty insurance, the Texas statutes contain no section on deviations. "Texas . . . has a single rating law for the fixing of casualty insurance rates. It does not permit the fixing of casualty rates on a flexible basis." 34

In addition to setting rates on automobile and casualty insurance, it appears that the Texas board also fixes rates on credit insurance. The Texas Consumers Credit Insurers Association has objected to the action of the Board of Insurance, and has charged that the setting of maximum rates is arbitrary, that there is no statutory authority for limiting types of coverage to the four forms prescribed by the board, and that the fixing of maximum commissions is a "new and nebulous field" for the board. ${ }^{35}$ Regardless of the validity of these objections,

30. The National Underwriter, March 7, 1958, p. 4 (fire and casualty ed.).

31. Id. at 29.

32. See 1 Nationad Board of Fire Underwriters, Committee on Laws, Comprlation of RAte Regulatory Laws, citing Tex. Rating Laws, ch. 5, art. 5.26; MEHR \& CAMMACK, op. cit. supra note 24 , at 822-23.

33. Texas Laws 1953, $\mathrm{ch}$. 30, reproduced in 2 NATIONAL BoARD of Fire UNDERWRITERS, COMMITTEE oN LAWS, Compilation OF RATE REgulatory LaWs.

34. Secrest, Toward a Flexible Future-The Policyholder's Stake, in ProceEdings, 13th ANnual Meeting of the National. Assoctation of INDEPENDENT INsurers

26 (Chicago 1957). (Hereinafter cited as ProceEdings.)

35. Journal of Commerce, Feb. 20, 1958, p. 5, col. 3. 
it is clear that regulation in Texas has gone beyond the mere approval or disapproval by the board of the practices, schedules and rates of the insurance companies.

Because Texas-type regulation has-fortunately, in our viewnot become widespread, we shall confine our attention to those forces and policies which affect the breadth of the area within which competition, i.e., independence and deviation, is permitted to operate.

In many states substantial roadblocks have been placed in the path of deviators (or more accurately, "would-be" deviators) by the activities of the rating bureaus. The model laws provided for the intervention of the bureaus in opposition to independent filing ${ }^{36}$ and the bureaus have certainly taken full advantage of that provision. The long harassment by the bureaus of the Insurance Company of North America is a case in point. A recent decision of the Supreme Court of Arizona, ${ }^{37}$ relating to the right of partial subscribership, is pertinent here as an illustration of an instance in which rating bureaus and insurance commissioners have attempted-in this case unsuccessfully-to enforce rate uniformity in the insurance industry.

The right of partial subscribership, guaranteed in the model bills, is important to a company that has sufficient loss experience on some types of insurance to sustain an independent filing but does not have the necessary data on all types of insurance to make the services of the bureau completely unnecessary to it. Without the right of partial subscribership, a company to whom some of the information collected by the bureau is indispensable must either use bureau rates on all types of insurance, or simply file deviations from some of those rates. As many states require deviations to be refiled each year, the deviation procedure is, at the least, cumbersome. Hence, partial subscribership is a right important to companies driving toward more independent rate structures.

The facts of the Arizona case were as follows. The North American Companies notified the Pacific Fire Rating Bureau of the termination of their subscribership to the rating services of that bureau for "dwelling classes"; the notice of termination stated that the insurance companies desired, however, to retain subscribership for the remaining services of PFRB. The bureau, after determining that its by-laws and constitution would not allow it to take disciplinary measures against the companies, amended its constitution to severely limit the

36. Proposed Fire, Marine and Inland Marine Rate Regulatory Bill, supra note 19, $\S 5(d)$; Proposed Casualty and Surety Rate Regulatory Bill, supra note 19, §5(d).

37. Pacific Fire Rating Bureau v. Insurance Co. of No. America, 83 Ariz. 369, 321 P.2d 1030 (1958). 
right of partial subscribership. This rule ${ }^{38}$ was approved by the director of insurance. The trial court held for the rating bureau, but the Supreme Court of Arizona reversed that decision and stated that rule vii "obviously precludes freedom of rate competition that results from partial subscribership. While the director may, under the statute, approve reasonable rules and regulations he cannot make or approve a rule, as here, that would conflict with the true meaning of the statute." 39

That it took a long legal battle to win a point which the model laws apparently made obvious cannot be ignored, and since most states require annual rejustification of deviations, such struggles over independent filings become even more important. Nevertheless, in this case at any rate, the battle was decided in favor of an expansion of the area of permitted rate rivalry.

Another problem facing potential deviators stems from the fact, cited above, ${ }^{40}$ that the statutes do not set out specific standards by which to determine whether or not a rate is "excessive, inadequate or unfairly discriminatory." One of the problems intertwined with this lack of a clear standard is: On the basis of what statistics should such a judgment of reasonableness of rates be made? This problem appears to arise only in connection with deviations and independent filings, for the approval (or disapproval) of bureau rates is predicated on the loss and expense experience data collected by the bureau from its members and subscribers. But in the case of individual filings, the insurance commissioner is faced with a dilemma. Should he place primary reliance on the loss experience of the insurer seeking approval of his individual filing? Should he place primary emphasis on the loss experience of all companies operating in the state? Those operating outside the state? Or should a deviation or independent filing only be allowed on the basis of a difference in expense? The problems of the insurance commissioners are further complicated by the classification of risks, for the commissioners are charged with ensuring that there shall be no discrimination-that is, the same rates must be charged for identical

38. Rule VII, as cited in the opinion, supra note 37, at 372, 321 P.2d at 1032 : “1. Partial services for a particular State or States shall be available to a subscriber $\therefore$ in the following cases only: (a) Where the subscriber limits its writings in the State or States covered by the application to the kind of insurance, subdivision, or class of risk, or the part or combination thereof, for which such partial services are requested. (b) Where the subscriber desires to utilize the services of the Bureau in a particular State or States for all kinds of insurance and subdivisions or classes of risk for which the Bureau promulgates rates and classifications except in a limited specialty field or fields designated in the application for partial subscriberșhip and approved by the Governing Committee. . ."

39. Pacific Fire Rating Bureau v. Insurance Co. of No. America, 83 Ariz. 369, 375, 321 P.2d 1030, 1034 (1958).

40. See text at p. 203 supra. 
risks. The practices in the states regarding justification of deviations and independent filings have varied widely. A few examples will serve to underscore this diversity.

At the end of 1957, the Virginia Supreme Court upheld an order of the State Corporation Commission forbidding Allstate Insurance Company to subdivide automobile collision classes beyond the subdivisions approved by the commission for the Virginia Insurance Rating Bureau. ${ }^{41}$ Allstate held that its own experience indicated that cars used for pleasure driving were less likely to be involved in accidents than were cars used daily for business. The rating bureau, however, did not employ any such sub-grouping in its classification and rate schedules. The commission denied Allstate's collision deviation, based on this sub-classification, on the grounds that all companies should be required to use the same general classification, and that Allstate's plan was unsound as it was based only on its own experience.

Logical questions to ask in regard to this decision are: As the rating bureau did not use this sub-classification, where and how was Allstate to obtain data to support its case if its own experience was insufficient proof? Why was its own experience an unsound basis for the sub-classification sought? Was it unsound solely because it differed from the experience of rating bureau members?

From the point of view of public interest, it should be pointed out that if there was or is a significant difference in the loss experience of collision insurance, as Allstate contended, depending on whether the automobile was operated for business or pleasure, then the cost of collisions is being borne disproportionately by the automobile operators who fall into the classification of those less prone to accidents.

An application by the Insurance Company of North America for a ten per cent deviation from filed fire insurance rates in Virginia met a similar fate. ${ }^{42}$ In this case, however, the basis for the dismissal was the fact that the company's expenses exceeded the expenses permitted by the commission's formula for a deviation of ten per cent; and the commission would not permit the company to absorb the difference by accepting a profit rate below the five per cent required by the formula.

In sharp contrast to the Virginia commission's policy on deviation justification is the policy adopted by the Ohio insurance department. In determining whether or not a rate deviation is justified, the Ohio

41. Allstate Ins. Co. v. Commonwealth, 199 Va. 434, 100 S.E.2d 31 (1957), discussed in The National Underwriter, Nov. 7, 1957, p. 39 (fire and casualty ed.).

42. Application of Insurance Co. of No. America and Phila. Fire \& Marine Ins. Co. for a Devisation of the Rates of the Va. Ins. Rating Bureau for Fire and Extended Coverage No. 13556 (Va. State Corp. Comm'n, Oct. 4, 1957). 
department recognizes loss experience in the following order of importance : ${ }^{43}$

(1) Ohio loss experience of the insurer;

(2) Ohio loss experience of other insurers or rating bureaus; and

(3) Loss experience of the insurer or other insurers or rating bureaus outside the State.

Thus, primary importance is attached to the experience of the particular insurance company filing the new rate. In addition, it is significant to note that the regulations of the Ohio Department of Insurance contain specific sections informing the insurance companies of the procedures to follow in filing deviations as to rules, coverages and forms. ${ }^{44}$

Something of a middle ground is occupied by the State of North Carolina. There, the insurance commissioner recently allowed Allstate to begin deviating fifteen per cent on fire and extended coverage; the deviation was justified on the basis of the company's record of expense saving. However, Allstate's requests for permission to deviate from the policy forms and manual rules were denied, the commissioner stating that North Carolina's statutes do not provide for such deviation. ${ }^{45}$

\section{ConCLUSION}

The foregoing facts and analysis make possible the following conclusions and recommendations. ${ }^{46}$

First, there seems to be little doubt that the related practices of independent filings and of deviations from bureau rates are becoming increasingly important. The responses to our questionnaire clearly

43. Ohio Dep't of Ins., Rating Section, Gen. Bunc. No. 26, Fining RequireMENTS-RATES, RULES AND Coverages $\$$ II, at 8 (Jan. 17, 1958).

44. Id. at 9,10 .

45. Journal of Commerce, Nov. 19, 1957, p. 8, col. 2.

46. The perfunctory nature of the annual reports of the commissioners and the fact that their decisions are not collected by a reporting service, nor even, in most instances, made available even in mimeographed form, has made it difficult to achieve complete coverage. The Subcommittee on Antitrust and Monopoly of the Senate Committee on the Judiciary is currently investigating the effectiveness of state regulation under Public Law 15. See remarks of Senator Kefauver, 104 CoNG. REC. 1491 (1958), and speech of Donald McHugh as reported in N.Y. Times, May 7, 1958, p. 58, col. 1. Hearings on airline insurance completed in the summer of 1958 indicated, according to Senator O'Mahoney, that "certain segments of the insurance business operate in a supervisory vacuum." He thereupon turned over to the Antitrust Division the accumulated data. The National Underwriter, Oct. 11, 1958, p. 1. In October 1958 , the committee's staff sent a questionnaire, the first of a series, to the state commissioners, calling for detailed information on their staff and departmental organization, licensing and examination policies and procedures, and any actions taken against restraints of trade. The Eastern Underwriter, Oct. 17, 1958, p. 5. Although the inquiry may, as it proceeds, provide additional proof that regulation by fifty-one commissioners, many with inadequate staffs, results in perfunctory, inflexible and inconsistent rate review, its results are unlikely to require substantial modification of our conclusions regarding treatment of deviations and independent filings. 
indicate this to be the case, and business journals provide corroborative evidence. $^{47}$ There can be no denying, of course, that the path of the independent or the deviator is not any easy one. An executive of one company has described the experience of independent companies in the following picturesque terms: "The company finds that the rating law in some states is not a road or a highway, but a winding cowpath lined with a forest of pressures and paved with the chuckholes of discouragement, stifling imagination, vision, logic and common sense." 48

A second conclusion which can be drawn from our study is that there is considerable interstate variation in treatment of deviations and independent filings. ${ }^{49}$ In this area, with the National Association of Insurance Commissioners or some industry group as the instrument, a drive towards greater uniformity seems in order. It is to be hoped that the NAIC will reach a determination, using standards as liberal as possible consonant with safety, regarding the extent to which individual company experience is acceptable in support of a deviation. Where such single firm data do not suffice-and it is our view that statistical techniques in the areas of sampling, etc., are now sufficiently refined to permit of a fairly precise determination of the reliability of such data-bureaus should be compelled to provide, at reasonable fees, data for any sub-classification which a company contends is worthy of consideration. The commissioner might, of course, decide that such a sub-group is not a useful one for purposes of rate-making, but such a decision will at least have been based on something more than whim or inertia. This procedure may, we admit, require an improvementqualitative and quantitative-in the staffs of the state commissions. Such, however, is the price of effective regulation.

A third conclusion which one can draw from the foregoing review is that the path of the deviator is not only difficult, but unnecessarily so. ${ }^{50}$ Measures to smooth that path should be given every consideration p. 24.

47. See, e.g., Price Competition in Fire Insurance, Bus. Week, May 28, 1949,

48. Edward S. McMahon, Vice President, Wabash Fire and Casualty Co., ProCEedINGs at 110; see Kenney, Rate Deviation Becomes Whipping Boy of Reactionaries in Insurance Indtustry, 58 U.S. INVESTOR 23 (1957).

49. There is, of course, wide variation also in the vigor and intensity with which state commissioners review bureau rates. The Wisconsin commissioner, for instance, on assuming office in November 1955, after an extensive review of fire insurance rates submitted by the Wisconsin bureau, disapproved them all and set a maximum $2.5 \%$ profit factor, cutting the suggested National Association of Insurance Commissioners' profit in half. This action was exceptional. See Kenney, Insurance Conminissioners Had Better Heed Wisconsin Supreme Court Decision, 69 U.S. INvesToR 35 (1958).

50. The attitude of the industry toward deviation was indicated by the reaction of Albert J. Smith, President of U.S. Aviation Underwriters, Inc., one of two groups writing hull and liability insurance for airlines, at hearings before the O'Mahoney subcommittee (see note 46 supra). According to Mr. Smith, competition was not only a "rat race," it also tended to be "stupid and vicious." See Kenney, Senate Subcomntittee Hearings Point up Valuable Lesson to Insturance Industry, 69 U.S. INVESTOR 31, 35 (1958). 
-within the framework of regulation based on statistically supported rate filings. Of extreme importance would be the adoption of some approach which would eliminate the necessity of annual justification of deviations from bureau rates. If a deviation is based on a time period long enough to establish the typical nature of the data on which the deviation is based, subsequent annual rejustification would seem unnecessary.

A fourth conclusion can be adduced from the above-cited information concerning the current functioning of the insurance regulatory process. One would expect that the increased pressure on insurers to justify their rates to state authorities would result in an improved rate structure. Such, in fact, seems to be the case. Improved classifications of fire occupancy hazards, uniform classification of expenses, formulae for adjusting rates more equitably on a class-by-class basis, and experience rating plans for multiple-location risks have all been introduced. ${ }^{51}$ More specifically, there are now 110 classes of fire risks as compared with twenty-six before 1944; most companies now tend to allocate expenses to the class of risk for which the costs are incurred, whereas no detailed or uniform breakdown of expense figures was compiled before 1949; and the recommended maximum permissible fire underwriting profit adopted at the Commissioners' convention has been reduced from eight per cent to six per cent. ${ }^{52}$

Finally, the experience of well over a decade with completely rewritten and revised state regulation of insurance suggests certain broader hypotheses regarding the use of conditional and partial exemptions from the antitrust laws. In the first place, given both the indifference with which state regulatory policy had viewed monopolistic rate-fixing prior to 1944 and the clearly interstate nature of the business, there was ample justification for the Department of Justice to assert jurisdiction over the industry. At this point, two alternative courses of action were open. The industry could have been policed by the Antitrust Division, with rating bureaus eventually reduced to an informational function; this would undoubtedly have sufficed to give the prevailing system of state rate regulation its quietus. Rates might then have been set by some variety of price leadership, with an informal, more or less precise, industry formula designed to fall short of vulnerable conscious parallelism. ${ }^{53}$ Price competition would have

51. Marryott, Mutual Insurance Under Rate Regulation, 15 LAW \& Contenr. Pвов. 540, 546-47 (1950).

52. WHITNEX, op. cit. supra note 2.

53. See Dirlam \& Kann, Famr Competition: The Law and Economics of ANTITRUst Policy 66-67, 126-29 (1954); RePoRT, op. cit. supra note 14, at 36-42. 
been freer than before, but Congress apparently felt that a threat to private and public welfare would still lurk in the potential - faint though it would be-of unrestrained price competition. Hence the second alternative appeared the more reasonable: to strengthen state regulation, infusing it with greater sensitivity to the degree of competition that is necessary to prevent exploitation, while at the same time reserving partial jurisdiction to federal antitrust. Accepting as reasonable the premise that completely unfettered competition in fire, casualty, and surety insurance rate-making is economically undesirable, the compromise embodied in Public Law 15 is defensible as a program. This is not to deny the existence of clear-cut support for the contention that regulation, as it has been imposed, has tended to make deviation more difficult than it would be were there no regulation. But unregulated competition in the sale of insurance is not one of the alternatives open to us. For better or worse, by state, or perhaps in the future by federal agencies, ${ }^{54}$ some form of regulation is here to stay. ${ }^{55}$ This situation antedated Public Law 15 and would survive its repeal.

Nor does it seem to us that espousal of a series of modifications of the current regulatory procedures-modifications designed to facilitate deviation and independent filings-is inconsistent with the position that unrestrained competition would be unworkable in the lines of insurance here under discussion. An increase in statistically supported nonbureau filings is quite a different thing from unfettered competitive rate-making of the type called for by the Sherman Act. The requirement that companies desiring to meet the lower rates of competitors must also statistically support their reductions ensures, given judicious regulation, that rate-cutting will not reach ruinous proportions. Only by cutting costs or improving experience could a company meet lower rates of a competitor; failing that, it would have to content itself with attempting to provide superior service.

Not to be overlooked in any assessment of the adequacy of the present system of regulation in this industry is the fact that antitrust exemption is only partial. As we pointed out earlier, acts of boycott, intimidation and coercion may still be prosecuted under the provisions of the Sherman Act. All indications are that the Department of Justice is moving vigorously in this area. A consent judgment has

54. For an interesting discussion of the likelihood of federal regulation see $\mathrm{KrM}$ ball \& Boyce, The Anequacy of State Insurance Rate Regulation: The McCarran-Ferguson Act in Historical Perspective, 56 Mich. L. Rev. 545, 576-78 (1958).

55. One attorney, writing in a somewhat different connection, has stated, "It is useless for those who deplore the growth in the number and authority of administrative bodies to wring their hands over a fait accompli." Miller, Administrative Laze: Must the Angels Weep?, 62 Dick. L. Rev. 205, 214-15 (1958). 
been obtained to put a halt to sales of funeral merchandise; ${ }^{56}$ and successful suits have been brought against boycotting practices of agents' associations. $^{.7}$ There can be little doubt that the Justice Department intends to continue its efforts along these lines. ${ }^{58}$ Significantly, overt industry support and enforcement of restrictive rules adopted by brokers' associations have been eliminated. ${ }^{59}$

A lesson of the McCarran Act seems to be, therefore, that if antitrust exemptions are to be made available there must be provision for the Department of Justice to move when the regulatory authorities are indifferent to the basic requirements for competition. ${ }^{60}$ True, this does not insure continuous supervision of the regulators, but this is too much to ask in our society. The continued threat of possible repeal of the McCarran Act, and of possible antitrust action under it, seem to have sufficed to produce a slow but discernible shift in the industry toward more flexible and independent pricing, and away from a series of undesirable trade practices. 1954.

56. United States v. Liberty Nat'l Life Ins. Co., Civil 7719-S, D. Ala., June 29,

57. United States v. New Orleans Ins. Exch., 148 F. Supp. 915 (E.D. La.), aff'd per curian, 355 U.S. 22 (1957); cf. United States v. Insurance Bd., 144 F. Supp. 684 (N.D. Ohio 1956). For a discussion of some of the restrictive rules used by agents' groups before the South-Eastern Underwriters Association decisions see Stelzer, supra note 3 , at 149; 1948 NEw YoRK StaTe JoInT LEGISLATIVE CoMMITTEE ON INSURANCE RATES AND REgULATTONS REPORT 19-20; Butler, Activities of Agents Under the McCarrain Act, 15 LaW \& ConTEMrp. Prob. 568, 571 (1950).

58. Address by Victor R. Hansen, "Antitrust and Regulation Problems in Insurance," delivered before the University of Arizona Program on Insurance Regulation, Tucson, Ariz., Jan. 21, 1958.

59. In March 1950 the National Association of Insurance Agents notified its branches that it would no longer aid in the enforcement of these rules. See Butler, supra note 57.

60. But of. von Mehren, The Antitrust Lazes and Regulated Industries: The Doctrite of Primary Jurisdiction, 67 HARv. L. REv. 929, especially 965-66 (1954). 